\title{
Late Established Mutans Streptococci in Children over 3 Years Old
}

\author{
Mitsugi Okada, ${ }^{1}$ Yoshiko Taniguchi, ${ }^{2}$ Fumiko Hayashi, ${ }^{3}$ Takako Doi, ${ }^{2}$ Junji Suzuki, ${ }^{3}$ \\ Motoyuki Sugai, ${ }^{4}$ and Katsuyuki Kozai ${ }^{3}$
}

${ }^{1}$ Department of Special Care Dentistry, Hiroshima University Hospital, 1-2-3, Kasumi, Minami-ku, Hiroshima 734-8553, Japan

${ }^{2}$ Department of Pediatric Dentistry, Hiroshima University Hospital, 1-2-3, Kasumi, Minami-ku, Hiroshima 734-8553, Japan

${ }^{3}$ Department of Pediatric Dentistry, Graduate School of Biomedical Sciences, Hiroshima University, 1-2-3, Kasumi, Minami-ku, Hiroshima 734-8553, Japan

${ }^{4}$ Department of Bacteriology, Graduate School of Biomedical Sciences, Hiroshima University, 1-2-3, Kasumi, Minami-ku, Hiroshima 734-8553, Japan

Correspondence should be addressed to Mitsugi Okada, mitsugi@hiroshima-u.ac.jp

Received 18 October 2009; Accepted 14 December 2009

Academic Editor: Alexandre R. Vieira

Copyright (C) 2010 Mitsugi Okada et al. This is an open access article distributed under the Creative Commons Attribution License, which permits unrestricted use, distribution, and reproduction in any medium, provided the original work is properly cited.

\begin{abstract}
Acquisition of mutans streptococci has been reported to most commonly occur at approximately 26 months of age. In the present study, we detected Streptococcus mutans and S. sobrinus using polymerase chain reaction (PCR) assays in children, then reexamined the subjects to determine the time of acquisition of these bacteria over a 1-year period. The subjects were 57 children ranging in age from 3 to 5 years old, each with primary dentition. Plaque samples were collected from all erupted tooth sites using a sterile toothbrush. PCR assays were performed to detect the targeted mutans streptococci at the beginning of the study (baseline) and after 1 year. At the baseline examination, the prevalence of $S$. mutans and S. sobrinus was $61.4 \%$ and $54.4 \%$, respectively, in all subjects, of whom $14(24.6 \%)$ were positive for S. mutans alone, 10 (17.5\%) for S. sobrinus alone, and 21 (36.8\%) for both S. mutans and S. sobrinus, with $12(21.1 \%)$ negative for both. After 1 year, 4 of $22(18.2 \%)$ subjects newly had acquired S. mutans and 15 of $26(57.7 \%)$ had aquired S. sobrinus, while $5(8.8 \%)$ remained negative for both bacteria. The age of the first positive S. mutans finding ranged from 49 to 71 months, while that for $S$. sobrinus ranged from 49 to 81 months old. Our results suggest that S. sobrinus becomes established later than $S$. mutans in the oral cavities of children over the age of 3 years old.
\end{abstract}

\section{Introduction}

Mutans streptococci, comprised of Streptococcus mutans and S. sobrinus, are considered to be the principal etiologic agents of dental caries in humans [1-3]. Preschool children harboring both $S$. mutans and S. sobrinus have a significantly higher incidence of dental caries than those with $S$. mutans alone [4]. Some studies have suggested that there is a "window of infectivity" for mutans streptococci at an early age, after which colonization is not likely to occur [5-7], and others have reported its predentate presence in infants as young as 3 months of age [8-10]. It was reported that 10 of 15 children acquired mutans streptococci during a 7-year period, and a second "window of infectivity" after the age of 5 when the permanent dentition erupts has been postulated [11]. Although several studies have attempted to determine the time of initial mutans streptococci acquisition, it remains controversial.
In several epidemiologic studies, identification of $S$. mutans and S. sobrinus on such selective media as mitissalivarius (MS) or MS-bacitracin (MSB) agar has been performed using colonial morphology methods [12-14]. However, accurate differentiation between S. mutans and S. sobrinus is not easy, as well as time-consuming and laborious [6], and it has been reported that S. sobrinus from dental plaque samples is especially difficult to culture directly on MSB selective medium [15, 16]. Thus, it is of great importance to distinguish the presence of these 2 species separately in children for accurate prediction and effective prevention of dental caries.

Thus far, several methods used for detecting and identifying mutans streptococci, including direct microscopy, cultivation, enzyme tests, monoclonal antibodies, enzymelinked immunosorbent assays, and species-specific DNA probes, have been reported [17-20]. Several investigators have also developed polymerase chain reaction (PCR) 
methods and found them to be more sensitive for detection, when compared to conventional culture techniques [2123 ], as they have been shown able to detect low numbers of bacterial species with a detection limit of as few as 25100 cells [22-24], while being quick and relatively simple to perform. Further, PCR assays have been reported suitable for the specific detection and identification of human cariogenic bacteria, such as $S$. mutans and S. sobrinus [22-25].

In the present study, we detected $S$. mutans and $S$. sobrinus using polymerase chain reaction (PCR) assays in preschool children, then re-examined the subjects to determine acquisition of those bacteria over a 1-year period.

\section{Materials and Methods}

Fifty-seven Japanese preschool children, aged 3 to 5 years old with primary dentition, who were visitors to Hiroshima University Hospital, were enrolled. Consent for participation was obtained from at least one of their parents prior to the study according to the ethical guidelines of the Declaration of Helsinki (1975). Those who had received antibiotics within the previous 3 months or with systemic diseases were excluded.

2.1. Plaque Sampling. Dental plaque samples at the beginning (baseline) of the study and after 1 year were collected from all erupted teeth by professionally brushing with a sterile toothbrush for 1 minute, using a previously described method [26]. Plaque adhering to the toothbrush was removed by washing several times in a tube of sterile distilled water. The plaque samples were immediately transported to our research laboratory and stored at $-20^{\circ} \mathrm{C}$, prior to extraction of genomic DNA. One year later, plaque samples were again obtained from the same subjects in the same manner.

2.2. Genomic DNA Preparation. Streptococcus mutans JCM5175 and S. sobrinus ATCC27607 were used as control organisms. PCR detection of the tested species was performed using primers, as previously described [22, 24], while that of $16 \mathrm{~S}$ ribosomal RNA encoding gene (GenBank accession number M75035) was used as previously described [27].

Plaque samples were first harvested by centrifugation at $1,600 \times \mathrm{g}$ for 20 minutes. The supernatants were discarded, and the individual cell pellets were stored at $-20^{\circ} \mathrm{C}$ until DNA isolation. A genomic DNA preparation from each plaque sample was obtained using a standard miniprep procedure [28], to which we added an RNase treatment [29]. DNA concentrations in the dental plaque samples were calculated by measuring A260 and the quality was estimated by the A260/A280 ratio [30].

2.3. Conditions of PCR Amplification. PCR amplification was performed in a reaction mixture $(25 \mu \mathrm{L})$ consisting of PCR beads (GE Healthcare UK Limited, UK) that contained an enzyme (Taq DNA polymerase), along with the required reagents, $25 \mathrm{pmol}$ of each primer, and 20 to $50 \mathrm{ng}$ of template
TABLE 1: Distribution of mutans streptococci at the base line.

\begin{tabular}{lcc}
\hline S. mutans & S. sobrinus & Number of subjects $(\%)$ \\
\hline+ & - & $14(24.6)$ \\
+ & + & $21(36.8)$ \\
- & + & $10(17.5)$ \\
- & - & $12(21.1)$ \\
\hline \multicolumn{3}{r}{ Total } \\
\hline
\end{tabular}

DNA solution in a thermal cycler (PC-700 program temp control system, ASTEC Co. Ltd., Fukuoka, Japan). Each set of PCR analyses included a negative control (water blank) in addition to the positive control. The reaction mixture was denatured at $95^{\circ} \mathrm{C}$ for 3 minutes, followed by a series of amplification-denaturation steps at $95^{\circ} \mathrm{C}$ for 1 minute, annealing at $55^{\circ} \mathrm{C}$ for 1 minute, and extension at $72^{\circ} \mathrm{C}$ for 1 minute, which was repeated for 26 cycles, with a final cycle at $94^{\circ} \mathrm{C}$ for 1 minute, $55^{\circ} \mathrm{C}$ for 1 minute, and $72^{\circ} \mathrm{C}$ for 5 minutes [22]. Following amplification, $15 \mu \mathrm{L}$ of the PCR products were analyzed by electrophoresis on a $1.2 \%$ agarose gel. After staining with ethidium bromide, the newly synthesized DNA fragments were visualized under a 302-nm ultraviolet light. The size of the PCR products was estimated from the electrophoretic migration of products relative to a 100 base-ladder marker (Amersham Pharmacia Biotech, AB, Uppsala, Sweden).

\section{Results}

Table 1 shows the distribution of mutans streptococci at the baseline examination. The prevalence of $S$. mutans and $S$. sobrinus was $61.4 \%$ and $54.3 \%$, respectively, in all subjects, of whom $14(24.6 \%)$ were positive for S. mutans alone, 10 (17.5\%) for S. sobrinus alone, and 21 (36.8\%) for both $S$. mutans and S. sobrinus, with $12(21.1 \%)$ negative for both S. mutans and S. sobrinus.

Table 2 shows the children that were found to have newly acquired mutans streptococci after 1 year and their ages. Four of $22(18.2 \%)$ subjects negative for S. mutans at the baseline had acquired S. mutans and 15 of $26(57.7 \%)$ S. sobrinus. The mean age for the first positive $S$. mutans and $S$. sobrinus result was $60.8 \pm 11.4$ months and $60.2 \pm 8.6$ months, respectively, while the age for the first positive $S$. mutans detection ranged from 49 to 71 months old and that for S. sobrinus ranged from 49 to 81 months old.

Figure 1(a) shows the distribution of $S$. mutans in different age groups at the baseline and after 1 year. Overall, the prevalence of $S$. mutans at the baseline and after 1 year was $61.4 \%$ and $64.9 \%$, respectively. In the 3 -year-old group, $12(66.7 \%)$ of 18 subjects were positive at the baseline and $13(72.2 \%)$ of those were positive for S. mutans after 1 year, while the same $13(59.1 \%)$ of 22 subjects in the 4 -year old group were found positive at both the baseline and after 1 year. In the 5-year old group, $10(58.8 \%)$ of 17 subjects were found positive for S. mutans at the baseline and $11(64.7 \%)$ were positive after 1 year. 


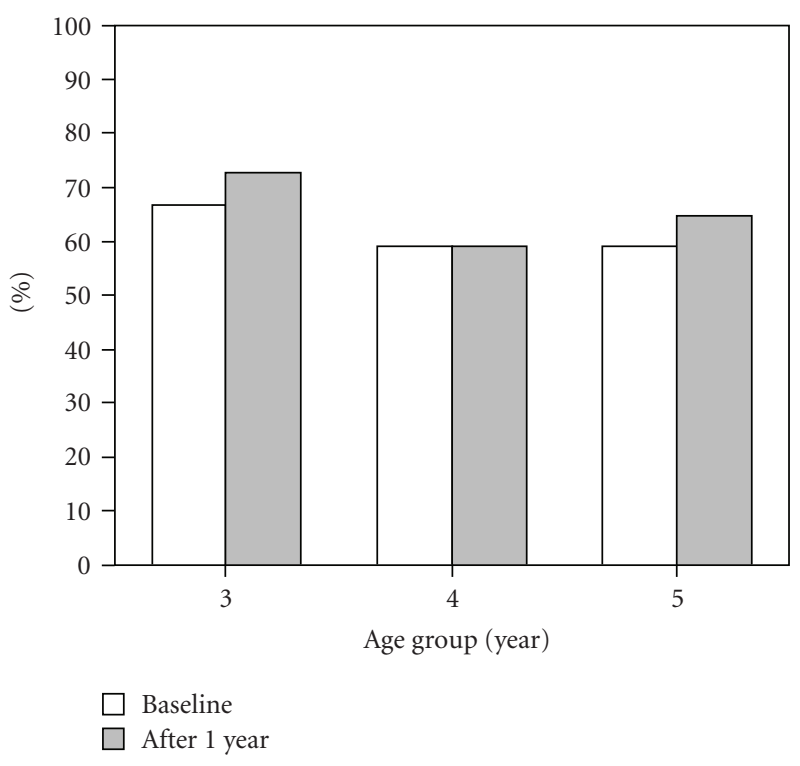

(a)

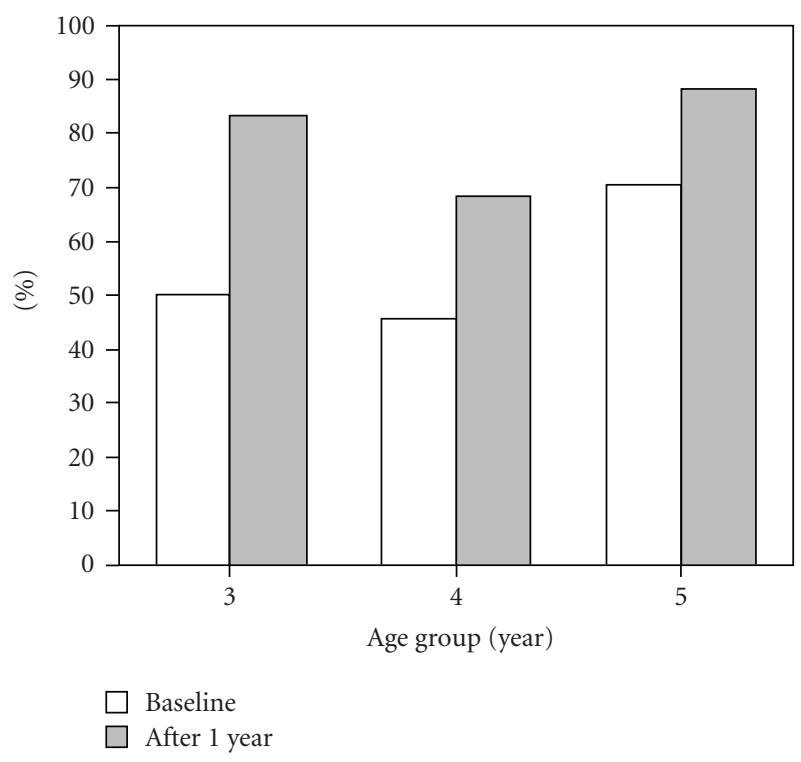

(b)

FIGURE 1: Distribution of S. mutans (a) and S. sobrinus (b) in different age groups at the baseline and after 1 year.

TABLE 2: Children and their ages with mutans streptococci acquired after 1 year.

\begin{tabular}{lccc}
\hline Organisms present & $\begin{array}{c}\text { Age }^{(\mathrm{a})} \\
(\mathrm{months})\end{array}$ & $\begin{array}{c}\text { Age range } \\
(\text { months) }\end{array}$ & $\begin{array}{c}\text { Number }(\%) \\
\text { of subjects }\end{array}$ \\
\hline S. mutans $(-\rightarrow+)$ & $60.8 \pm 11.4$ & $49-71$ & $4 / 22(18.2)$ \\
S. sobrinus $(-\rightarrow+)$ & $60.2 \pm 8.6$ & $49-81$ & $15 / 26(57.7)$ \\
\hline (a) Mean age \pm Standard deviation. & &
\end{tabular}

Figure 1(b) shows the distribution of $S$. sobrinus in different age groups at the baseline and after 1 year. Overall, the prevalence of $S$. sobrinus at the baseline and after 1 year was $54.4 \%$ and $78.9 \%$, respectively. In the 3 -year old group, $9(50.0 \%)$ of 18 subjects were found positive at the baseline and $15(83.3 \%)$ were positive for S. sobrinus after 1 year. In the 4-year old group, $10(45.5 \%)$ of 22 and 15 $(68.2 \%)$ of 22 were shown to be positive at the baseline and after 1 year, respectively, while $12(70.6 \%)$ of 17 and 15 $(88.2 \%)$, respectively, were positive in the 5 -year old group. The increased ratios (number of positive subjects after 1 year/number of those at the baseline) for S. mutans were 1.1, 1.0 , and 1.1 , at 3,4 , and 5 years of age, respectively, while the ratios for S. sobrinus were 1.7, 1.5, and 1.3, respectively.

\section{Discussion}

We performed a longitudinal study to determine whether mutans streptococci are frequently established in the oral cavities of children during a discrete-time period, known as the "window of infectivity," that is considered to range from 19 to 31 months of age, with a median age of 26 months [5], and the time of emergence of the primary molars $[7,31]$. The majority of studies have suggested that mutans streptococci are not found until teeth erupt and become attachment sites for permanent oral bacterial colonization [5-7], though some authors have mentioned its predentate presence [8$10]$.

In the present longitudinal study, the PCR method used to detect $S$. mutans and S. sobrinus with $16 \mathrm{~S}$ rRNA primers confirmed the presence of bacteria in all plaque samples (data not shown). This tool provides a more sensitive means of detection of cariogenic bacterial species, as compared with conventional cultural techniques [22, 24, 32]. Further, it has been reported that mitis-salivarius bacitracin inhibits the growth of $S$. sobrinus more than that of $S$. mutans $[15,16]$, and the recovery of $S$. sobrinus can be significantly underestimated using conventional cultural techniques [33]. We conclude that results of the present study show that this PCR method is suitable for investigation of the intra-oral distribution of S. sobrinus as well as S. mutans.

The prevalence of $S$. mutans and S. sobrinus at the baseline investigation conducted at 3 years old was $66.7 \%$ and $50.0 \%$, respectively, and $27.8 \%$ for both, which is in agreement with other reports of preschool children [3436]. The prevalence of children positive for $S$. mutans was constant in each age group at both the baseline and 1 year examinations. It has been suggested that $S$. mutans generally becomes established in the oral cavity of children before the age of 3 years old. However, the prevalence of children positive for S. sobrinus after 1 year was higher than that at the baseline, with increase ratios of 1.7, 1.5, and 1.3 in the 3-, 4-, and 5-year-old groups, respectively, indicating that the rate of increase gradually slowed. Further, $57.7 \%$ of all the subjects eventually acquired $S$. sobrinus and their mean age for the first positive detection was 60 months, of whom $18.2 \%$ had S. mutans detected first. It was also noted that $S$. sobrinus was frequently found in the oral cavities of children without 
S. mutans after 3 years of age. Therefore, it is suggested that S. sobrinus is established later in the oral cavity of children as compared to $S$. mutans and that acquisition of S. sobrinus is still possible after the so-called "window of infectivity."

In the present study, 7 (50.0\%) of the 14 subjects with $S$. mutans became colonized with S. sobrinus, while $2(20.0 \%)$ of 10 subjects with $S$. sobrinus were first found positive for S. mutans. Considering the means of colonization by mutans streptococci, we speculate that $S$. sobrinus might easily colonize after the colonization of $S$. mutans, allowing it to become established in the oral cavity of S. mutans positive children. It is also suggested that the colonization of $S$. sanguinis may have an influence on subsequent colonization by mutans streptococci [37]. Further studies are required to understand the timing of initial infection with $S$. mutans and S. sobrinus.

The transmission to and colonization of mutans streptococci in the oral cavity are important factors for the prevention of dental caries. Previous studies have suggested that earlier colonization of $S$. mutans is related to a higher caries risk [34], and that children harboring both S. mutans and S. sobrinus showed a significantly higher incidence of dental caries than those with $S$. mutans alone in studies that used a conventional cultural [38], indirect immunofluorescence [39], and PCR methods [32]. In addition, the level of mutans streptococci in saliva has been shown to correlate both with past caries experience $[40,41]$ and future caries activity [42, $43]$. We previously reported that incremental caries increases were significantly greater in children with both $S$. mutans and S. sobrinus, as compared to those with $S$. mutans alone [4]. Based on the present results, it is predicted that caries risk will increase in 3-year-old children with $S$. mutans already established, since $S$. sobrinus can become established after 3 years of age. We considered that the present results are highly relevant for development of prevention strategies for caries in childhood, as delayed acquisition of mutans streptococci might reduce the number of caries experienced in primary and permanent dentition at later ages [44].

In conclusion, our results suggest that $S$. sobrinus becomes established later in the oral cavity of children over the age of 3 years old as compared to $S$. mutans.

\section{Acknowledgment}

This work was supported in part by a grant-in-aid 15791210 from the Ministry of Education, Science, Sports and Culture of Japan.

\section{References}

[1] N. Masuda, N. Tsutsumi, S. Sobue, and S. Hamada, "Longitudinal survey of the distribution of various serotypes of Streptococcus mutans in infants," Journal of Clinical Microbiology, vol. 10, no. 4, pp. 497-502, 1979.

[2] W. J. Loesche, "Role of Streptococcus mutans in human dental decay," Microbiological Reviews, vol. 50, no. 4, pp. 353-380, 1986.

[3] P. D. Marsh, A. Featherstone, A. S. McKee, et al., "A microbiological study of early caries of approximal surfaces in schoolchildren," Journal of Dental Research, vol. 68, no. 7, pp. 1151-1154, 1989.

[4] M. Okada, Y. Soda, F. Hayashi, et al., "Longitudinal study of dental caries incidence associated with Streptococcus mutans and Streptococcus sobrinus in pre-school children," Journal of Medical Microbiology, vol. 54, no. 7, pp. 661-665, 2005.

[5] P. W. Caufield, G. R. Cutter, and A. P. Dasanayake, "Initial acquisition of mutans streptococci by infants: evidence for a discrete window of infectivity," Journal of Dental Research, vol. 72, no. 1, pp. 37-45, 1993.

[6] F. M. Florio, M. I. Klein, A. C. Pereira, and R. B. Goncalves, "Time of initial acquisition of mutans streptococci by human infants," Journal of Clinical Pediatric Dentistry, vol. 28, no. 4, pp. 303-308, 2004.

[7] R. Berkowitz, "Etiology of nursing caries: a microbiologic perspective," Journal of Public Health Dentistry, vol. 56, no. 1, pp. 51-54, 1996.

[8] P. Milgrom, C. A. Riedy, P. Weinstein, A. C. R. Tanner, L. Manibusan, and J. Brass, "Dental caries and its relationship to bacterial infection, hypoplasia, diet, and oral hygiene in 6- to 36-month-old children," Community Dentistry and Oral Epidemiology, vol. 28, no. 4, pp. 295-306, 2000.

[9] A. K. L. Wan, W. K. Seow, L. J. Walsh, P. Bird, D. I. Tudehope, and D. M. Purdie, "Association of Streptococcus mutans infection and oral developmental nodules in predentate infants," Journal of Dental Research, vol. 80, no. 10, pp. 1945-1948, 2001.

[10] A. K. L. Wan, W. K. Seow, D. M. Purdie, P. S. Bird, L. J. Walsh, and D. I. Tudehope, "Oral colonization of Streptococcus mutans in six-month-old predentate infants," Journal of Dental Research, vol. 80, no. 12, pp. 2060-2065, 2001.

[11] B. Lindquist and C. G. Emilson, "Colonization of Streptococcus mutans and Streptococcus sobrinus genotypes and caries development in children to mothers harboring both species," Caries Research, vol. 38, no. 2, pp. 95-103, 2004.

[12] O. G. Gold, H. V. Jordan, and J. van Houte, "A selective medium for Streptococcus mutans," Archives of Oral Biology, vol. 18, no. 11, pp. 1357-1364, 1973.

[13] W. G. Wade, M. J. Aldred, and D. M. Walker, "An improved medium for isolation of Streptococcus mutans," Journal of Medical Microbiology, vol. 22, no. 4, pp. 319-323, 1986.

[14] M. Svanberg and B. Krasse, "Comparative recovery of mutans streptococci on two selective media," Caries Research, vol. 24, no. 1, pp. 36-38, 1990.

[15] J. J. de Soet, P. J. van Dalen, M. J. Pavicic, and J. de Graaff, "Enumeration of mutans streptococci in clinical samples by using monoclonal antibodies," Journal of Clinical Microbiology, vol. 28, no. 11, pp. 2467-2472, 1990.

[16] H. V. Jordan, "Cultural methods for the identification and quantitation of Streptococcus mutans and lactobacilli in oral samples," Oral Microbiology and Immunology, vol. 1, no. 1, pp. 23-30, 1986

[17] S. Hamada and H. D. Slade, "Biology, immunology, and cariogenicity of Streptococcus mutans," Microbiological Reviews, vol. 44, no. 2, pp. 331-384, 1980.

[18] D. M. Kemeny, R. Urbanek, D. Richards, and C. Greenall, "Development of a semi-quantitative enzyme-linked immunosorbent assay (ELISA) for detection of human IgG subclass antibodies," Journal of Immunological Methods, vol. 96, no. 1, pp. 47-56, 1987.

[19] D. Beighton, J. M. Hardie, and R. A. Whiley, "A scheme for the identification of viridans streptococci," Journal of Medical Microbiology, vol. 35, no. 6, pp. 367-372, 1991. 
[20] K. Kikuchi, T. Enari, K.-I. Totsuka, and K. Shimizu, "Comparison of phenotypic characteristics, DNA-DNA hybridization results, and results with a commercial rapid biochemical and enzymatic reaction system for identification of viridans group streptococci," Journal of Clinical Microbiology, vol. 33, no. 5, pp. 1215-1222, 1995.

[21] T. Ono, K. Hirota, K. Nemoto, E. J. Fernandez, F. Ota, and K. Fukui, "Detection of Streptococcus mutans by PCR amplification of spaP gene," Journal of Medical Microbiology, vol. 41, no. 4, pp. 231-235, 1994.

[22] T. Igarashi, A. Yamamoto, and N. Goto, "PCR for detection and identification of Streptococcus sobrinus," Journal of Medical Microbiology, vol. 49, no. 12, pp. 1069-1074, 2000.

[23] T. Oho, Y. Yamashita, Y. Shimazaki, M. Kushiyama, and T. Koga, "Simple and rapid detection of Streptococcus mutans and Streptococcus sobrinus in human saliva by polymerase chain reaction," Oral Microbiology and Immunology, vol. 15, no. 4, pp. 258-262, 2000.

[24] T. Igarashi, A. Yamamoto, and N. Goto, "Direct detection of Streptococcus mutans in human dental plaque by polymerase chain reaction," Oral Microbiology and Immunology, vol. 11, no. 5, pp. 294-298, 1996.

[25] T. Shiroza, N. Shinozaki, T. Watanabe, T. Ikemi, K. Fukushima, and Y. Abiko, "Rapid isolation of chromosomal DNA from oral streptococci and polymerase chain reaction-oriented restriction fragment-length polymorphism analysis for genetic heterogeneity," Oral Microbiology and Immunology, vol. 13, no. 1, pp. 11-16, 1998.

[26] M. Okada, F. Hayashi, and N. Nagasaka, "Detection of Actinobacillus actinomycetemcomitans and Porphyromonas gingivalis in dental plaque samples from children 2 to 12 years of age," Journal of Clinical Periodontology, vol. 27, no. 10, pp. 763-768, 2000.

[27] P. Goncharoff, D. H. Figurski, R. H. Stevens, and D. H. Fine, "Identification of Actinobacillus actinomycetemcomitans: polymerase chain reaction amplification of $1 \mathrm{ktA}$-specific sequences," Oral Microbiology and Immunology, vol. 8, no. 2, pp. 105-110, 1993.

[28] K. Wilson, "Preparation of genomic DNA from bacteria," in Current Protocols in Molecular Biology, F. M. Ausubel, R. Brent, R. E. Kingston, et al., Eds., pp. 2.4.1-2.4.2, Wiley Interscience, Philadelphia, Pa, USA, 1990.

[29] G. L. Smith, S. S. Socransky, and C. M. Smith, "Rapid method for the purification of DNA from subgingival microorganisms," Oral Microbiology and Immunology, vol. 4, no. 1, pp. 47-51, 1989.

[30] J. Sambrook, E. F. Fritsch, and T. Maniatis, Molecular Cloning: A Laboratory Manual, Cold Spring Harbor Laboratory, Cold Spring Harbor, NY, USA, 2nd edition, 1989.

[31] U. Tedjosasongko and K. Kozai, "Initial acquisition and transmission of mutans streptococci in children at day nursery," Journal of Dentistry for Children, vol. 69, no. 3, pp. 284-288, 2002.

[32] M. Okada, Y. Soda, F. Hayashi, et al., "PCR detection of Streptococcus mutans and S. sobrinus in dental plaque samples from Japanese pre-school children," Journal of Medical Microbiology, vol. 51, no. 5, pp. 443-447, 2002.

[33] J. J. de Soet, P. J. van Dalen, B. J. Appelmelk, and J. de Graaff, "Identification of Streptococcus sobrinus with monoclonal antibodies," Journal of Clinical Microbiology, vol. 25, no. 12, pp. 2285-2288, 1987.

[34] B. Köhler, I. Andréen, and B. Jonsson, "The earlier the colonization by mutans streptococci, the higher the caries prevalence at 4 years of age," Oral Microbiology and Immunology, vol. 3, no. 1, pp. 14-17, 1988.

[35] Y. Li, J. M. Navia, and P. W. Caufield, "Colonization by mutans streptococci in the mouths of 3- and 4-year-old Chinese children with or without enamel hypoplasia," Archives of Oral Biology, vol. 39, no. 12, pp. 1057-1062, 1994.

[36] A. K. L. Wan, W. K. Seow, D. M. Purdie, P. S. Bird, L. J. Walsh, and D. I. Tudehope, "A longitudinal study of Streptococcus mutans colonization in infants after tooth eruption," Journal of Dental Research, vol. 82, no. 7, pp. 504-508, 2003.

[37] P. W. Caufield, A. P. Dasanayake, Y. Li, Y. Pan, J. Hsu, and J. M. Hardin, "Natural history of Streptococcus sanguinis in the oral cavity of infants: evidence for a discrete window of infectivity," Infection and Immunity, vol. 68, no. 7, pp. 4018-4023, 2000.

[38] H. Hirose, K. Hirose, E. Isogai, H. Miura, and I. Ueda, "Close association between Streptococcus sobrinus in the saliva of young children and smooth-surface caries increment," Caries Research, vol. 27, no. 4, pp. 292-297, 1993.

[39] K. G. Babaahmady, S. J. Challacombe, P. D. Marsh, and H. N. Newman, "Ecological Study of Streptococcus mutans, Streptococcus sobrinus and Lactobacillus spp. at sub-sites from approximal dental plaque from children," Caries Research, vol. 32, no. 1, pp. 51-58, 1998.

[40] K. Kristoffersson, P. Axelsson, D. Birkhed, and D. Bratthall, "Caries prevalence, salivary Streptococcus mutans and dietary scores in 13-year-old Swedish schoolchildren," Community Dentistry and Oral Epidemiology, vol. 14, no. 4, pp. 202-205, 1986.

[41] E. Newbrun, T. Matsukubo, C. I. Hoover, et al., "Comparison of two screening tests for Streptococcus mutans and evaluation of their suitability for mass screenings and private practice," Community Dentistry and Oral Epidemiology, vol. 12, no. 5, pp. 325-331, 1984.

[42] B. Köhler, B. M. Pettersson, and D. Bratthall, "Streptococcus mutans in plaque and saliva and the development of caries," Scandinavian Journal of Dental Research, vol. 89, no. 1, pp. 1925, 1981.

[43] B. Peretz, F. Sarit, E. Eidelman, and D. Steinberg, "Mutans streptococcus counts following treatment for early childhood caries," Journal of Dentistry for Children, vol. 70, no. 2, pp. 111114, 2003.

[44] M. M. E. Straetemans, C. van Loveren, J. J. de Soet, J. de Graaff, and J. M. ten Cate, "Colonization with mutans streptococci and lactobacilli and the caries experience of children after the age of five," Journal of Dental Research, vol. 77, no. 10, pp. 1851-1855, 1998. 


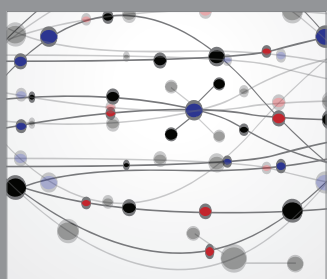

The Scientific World Journal
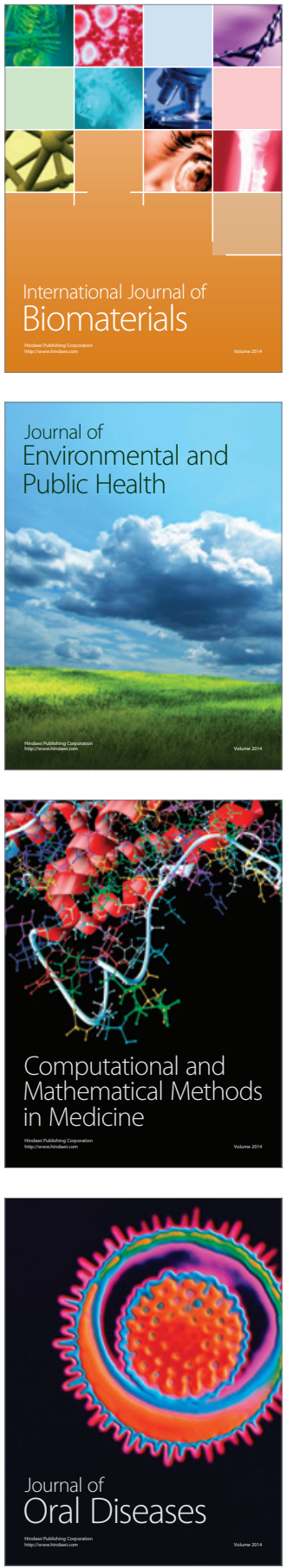
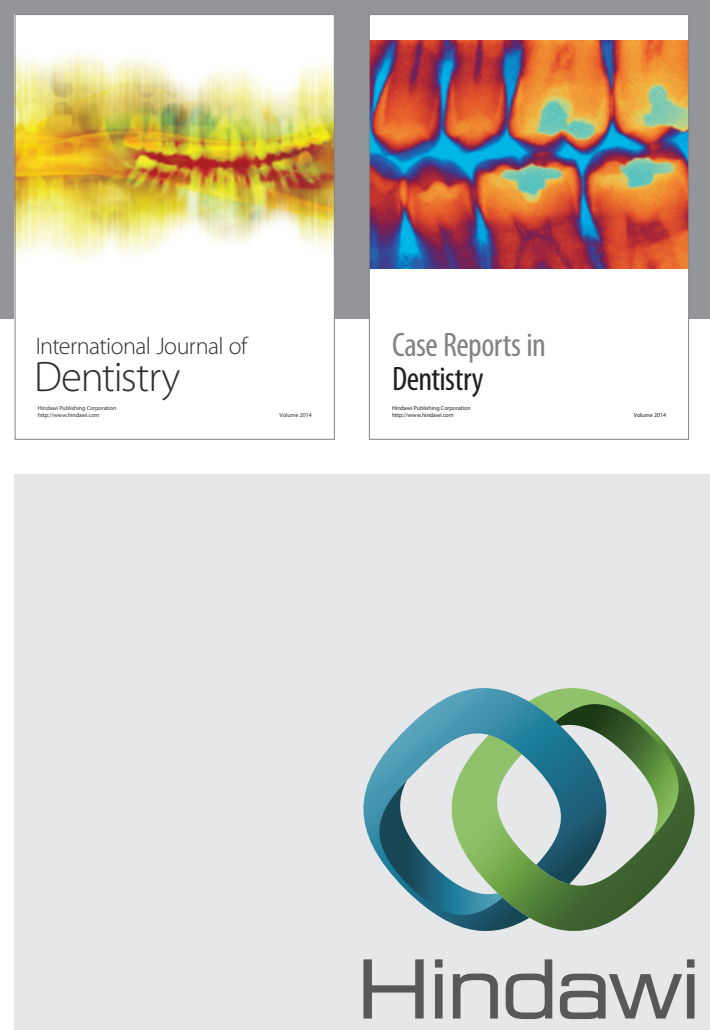

Submit your manuscripts at

http://www.hindawi.com
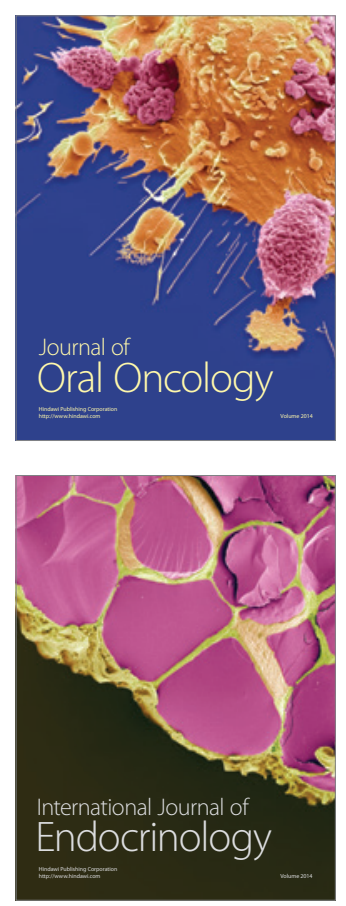
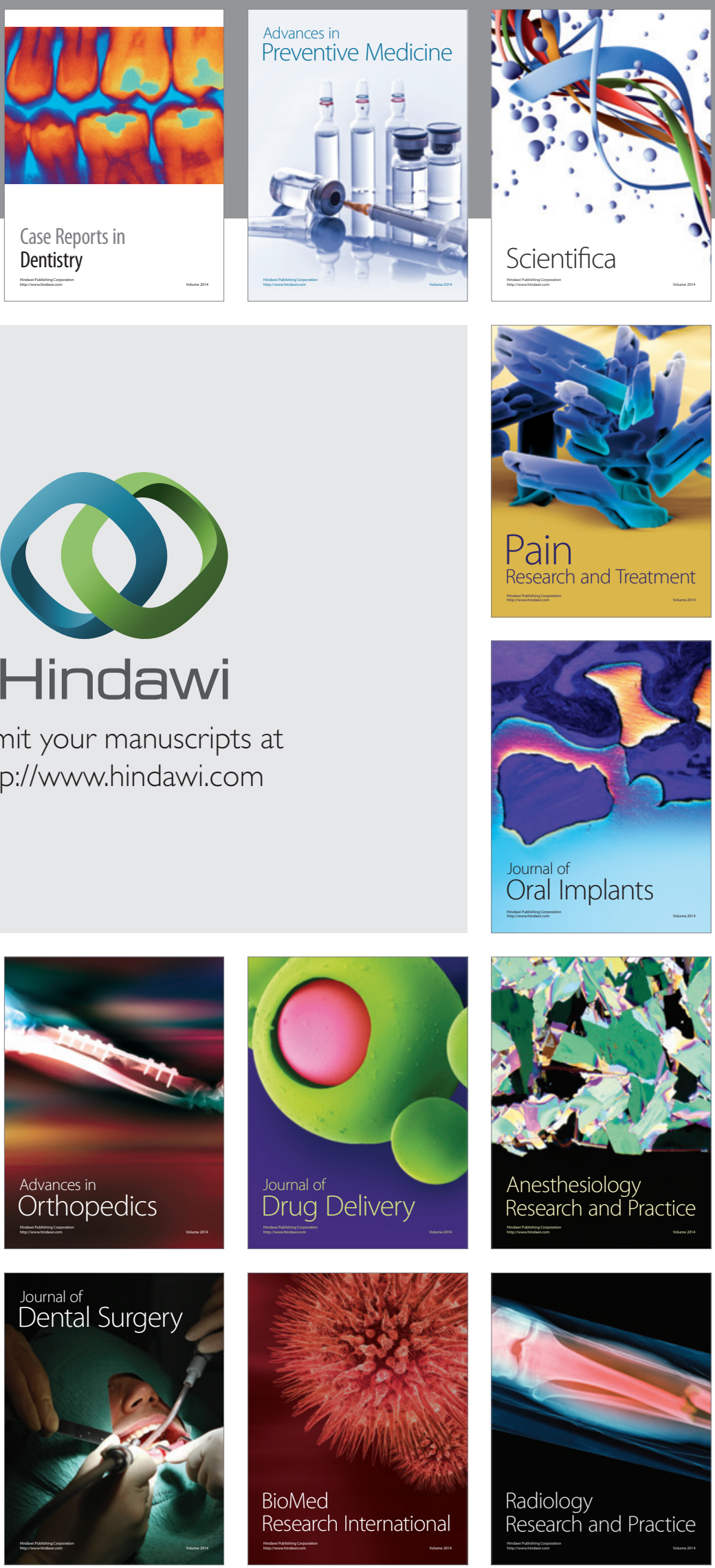